\title{
Levels of thrombopoietin in aqueous humor of patients with noninfectious acute anterior uveitis
}

\author{
This article was published in the following Dove Press journal: \\ Clinical Ophthalmology \\ 13 July 2015 \\ Number of times this article has been viewed
}

\author{
José-Juan Mondejar ${ }^{1,4}$ \\ David Salom ${ }^{1,3}$ \\ Salvador Garcia-Delpech ${ }^{1,2}$ \\ Manuel Diaz-Llopis' \\ 'Ophthalmology Department, \\ School of Medicine, University \\ of Valencia, ${ }^{2}$ Ophthalmology \\ Department, Hospital Universitario \\ La Fe, ${ }^{3}$ Ophthalmology Department, \\ Hospital de Manises, Valencia, \\ ${ }^{4}$ Ophthalmology Department, \\ Hospital General Universitario de \\ Alicante, Alicante, Spain
}

Purpose: To measure thrombopoietin (TPO) levels in the serum and aqueous humors of patients with noninfectious acute anterior uveitis.

Methods: A prospective, comparative, controlled study. Serum and aqueous humors were obtained from the eyes of 16 patients with noninfectious acute anterior uveitis. TPO levels were measured using an enzyme-linked immunosorbent assay (ELISA). The results obtained were compared with those of a control group.

Results: Serum concentrations of TPO were not significantly different between control individuals and patients with active anterior uveitis. Aqueous humor TPO levels were $54.46 \pm 16.24 \mathrm{pg} / \mathrm{mL}$ in the eyes of patients with uveitis, and $34.32 \pm 11.63 \mathrm{pg} / \mathrm{mL}$ in the eyes of controls. The difference between the two groups was significant (Mann-Whitney $U$-test for independent data, $P=0.0008$ ), with uveitis patients exhibiting significantly higher levels of TPO.

Conclusion: The high levels of TPO in the aqueous humors of uveitis patients points toward a cytoprotective role of this factor in inflammatory repair processes and the recovery of tissue homeostasis.

Keywords: TPO, thrombopoietin, aqueous humors, serum, acute anterior uveitis, cytoprotective

\section{Introduction}

The annual incidence of anterior uveitis in the United States is 8 per 100,000 inhabitants. ${ }^{1}$ Its origin is generally idiopathic; the event or agent that triggers the inflammation is unknown. ${ }^{1}$ There is no direct evidence that noninfectious anterior acute uveitis is an autoimmune disease, but various environmental and genetic stimuli, along with innate and adaptive immune responses, relate to this type of uveitis. Some cytokines are found in the eyes and peripheral blood of patients with uveitis. ${ }^{2-5}$ Some recent studies have reported increased levels of cell growth factors, such as pigment epithelium derived factor (PEDF) $)^{6-8}$ and vascular endothelial growth factor (VEGF), in the aqueous humors of patients with uveitis - both with and without macular edema, and even during periods of disease inactivity., ${ }^{9,10}$

Cell growth factors control cell growth and differentiation; regulating development and cell survival. They perform a crucial role in controlling cell proliferation. Alterations in signaling mediated by growth factors may be related to several inflammatory diseases. They also mutually interact to promote various healing or cell proliferation processes. ${ }^{11-18}$

Thrombopoietin (TPO) is a growth factor synthesized mainly in the liver. It is the main regulator of the proliferation and maturation of megakaryocytes and of the production of platelets, by which hematopoietic stem cells are regulated. It is also a positive vasculogenesis regulator, ${ }^{19-21}$ and its relationship with VEGF has been shown
Correspondence: José-Juan Mondejar Ophthalmology Department, School of Medicine, University of Valencia, Plaza Policia Local I-I-13, 460I5 Valencia, Spain

Email josejuanmondejar@gmail.com 
to be essential for stem cells, inducing their production and specifically promoting the production of two VEGF-A isoforms, VEGF121 and VEGF165 isoforms. VEGF also modulates the effects of TPO on hematological stem cells in an autocrine loop. ${ }^{22}$ It has also been implicated in the pathophysiology of multiple inflammatory and immunoallergic conditions such as allergic asthma or inflammatory bowel disease, in which it appears to play a significant immunoregulatory role. ${ }^{23,24}$ Studies with experimental mice models have demonstrated that VEGF acts as an acute-phase protein, and that its synthesis is induced by interleukin (IL)- $6 .{ }^{25}$ However, no studies of TPO levels in the aqueous humors of patients with uveitis have been reported to date.

This factor has been implicated in the pathophysiology of multiple inflammatory and immunoallergic conditions, where it could play an immunoregulatory role. The objective of the present study was to quantitatively measure TPO levels in the aqueous humors of patients with noninfectious acute anterior uveitis to establish whether or not they are impaired in these conditions.

\section{Materials and methods}

This is a single-center, non-randomized, controlled, prospective, observational, comparative case study which evaluates TPO levels in the serum and aqueous humors of patients with noninfectious anterior uveitis referred to the Uveitis Unit of the Department of Ophthalmology of the Hospital Universitario La Fe (Valencia, Spain), a center of national reference for the study and treatment of this condition. Controls were obtained from the serum and aqueous humors of patients who were due to have cataract surgery, and who had no history of intraocular inflammatory disease, systemic disease or long-term drug therapy.

The study protocol met the requirements of the Declaration of Helsinki, and was reviewed and approved by the Ethics Committee of the Hospital Universitario La Fe. Informed consent was obtained from all participants and specified the reason for the study.

The patient inclusion and exclusion criteria for the study were as follows: ${ }^{26}$

Inclusion criteria:

1. Diagnosis of classic acute anterior uveitis.

2. Untreated patients in the first episode of classic anterior uveitis, within the first 2-7 days of symptomatology. Eye inflammation (slit lamp microscopy grading of cells) rated moderate to severe (grade 2 to 4 ) according to the criteria of the International Ocular Inflammation Society and the Standardization Uveitis Nomenclature. ${ }^{26,27}$
Exclusion Criteria:

1. Diagnosis of hypertensive or granulomatous uveitis.

2. Specific clinical conditions, including Fuchs heterochromic iridocyclitisor Posner-Schlossman syndrome, uveitis caused by herpes, or toxoplasma in the aqueous humor sample, revealed by polymerase chain reaction (PCR).

3. Eye surgery in the 6 months prior to obtaining the sample.

4. Serology positive for HIV, syphilis or sarcoidosis (the latter revealed by angiotensin converting enzyme serum detection).

5. Cystoid macular edema, detected using optical coherence tomography (OCT).

6. Associated systemic diseases in the clinical history or revealed by clinical-radiological examination, or by HLA-B27 test.

Serum was obtained from peripheral blood of patients and controls.

Anterior chamber paracentesis prophylaxis, consisting of topical application of ofloxacin eye drops for three days, was performed before and after removal of aqueous humors. Immediately before removal, iodinated povidone in an ophthalmic dilution was applied to the conjunctival sac. ${ }^{28}$ Paracentesis for sampling was performed at the clinic with a $30 \mathrm{G}$ needle, with the aid of a slit lamp. Samples of at least $0.05-0.2 \mathrm{~mL}$ of aqueous humor were collected from each patient, and placed in sterile tubes and were stored immediately at $-80^{\circ} \mathrm{C}$ for subsequent processing. The specimens were classified and labeled in a masked fashion. All specimens were assayed for TPO in a double-blind arrangement with respect to their group. In the control group, composed of patients due to undergo cataract surgery, aqueous humors were removed immediately prior to surgery. The control group was age-matched with the uveitis group.

Quantitative measurement of protein concentrations in serum and aqueous humor samples was performed using the enzyme-linked immunosorbent assay (ELISA), marketed by Searchlights Human Angiogenesis Array ${ }^{\circledR}$ (Pierce Biotechnology, Inc., Rockford, IL, USA).

The TPO value in standard curves was in the range of $12-3,000 \mathrm{pg} / \mathrm{mL}$ and the sensitivity of TPO measurement was $5.9 \mathrm{pg} / \mathrm{mL}$. All procedures were performed on the same day, and according to the manufacturer's instructions.

The demographic data of the subjects were analyzed using the Windows statistical package SPSS Statistics for Windows, Version 19.0 (IBM Corp., Armonk, NY, USA). The MannWhitney $U$-test for independent data was used to compare TPO levels in the groups, accepting $P<0.05$ as a significant value. 


\section{Results}

A total of 32 serum and aqueous humor samples were obtained from 16 patients with uveitis (nine male and seven female), and 16 controls (ten male and six female). All patients were Caucasian. No statistically significant differences were detected between the mean ages of the patients with uveitis (mean \pm standard deviation [SD]; 51.6 \pm 12.5 years, range 35-79 years), and controls (59.2 \pm 11.2 years, range $44-79$ years), Student's $t$-test for independent data, $P=0.08$.

With respect to the control group, the sensitivity of the ELISA test used was $5.9 \mathrm{pg} / \mathrm{mL}$. Table 1 shows the values obtained for TPO levels according to the ELISA technique in both groups. The mean TPO level measured in serum samples was $35.4 \pm 12.94 \mathrm{pg} / \mathrm{mL}$ (range $21.1-61.2 \mathrm{pg} / \mathrm{mL}$ ) in patients with uveitis, and $32.87 \pm 9.8 \mathrm{pg} / \mathrm{mL}$ (range $15.3-50.7 \mathrm{pg} / \mathrm{mL}$ ) in controls. No statistically significant difference was found between the control group and the individualized patients with anterior uveitis (Mann-Whitney $U$-test, $P=0.82$ ).

The mean TPO level measured in the aqueous humor samples was $54.46 \pm 16.24 \mathrm{pg} / \mathrm{mL}$ (range $32.50-86.30 \mathrm{pg} / \mathrm{mL}$ ) in patients with uveitis, and $34.32 \pm 11.63 \mathrm{pg} / \mathrm{mL}$ (range $14.80-51.20 \mathrm{pg} / \mathrm{mL}$ ) in controls. A significant difference was found between the two groups (Mann-Whitney $U$-test, $P=0.0008$ ), with the patients with uveitis exhibiting significantly higher levels of TPO than the control group (Figure 1).

\section{Discussion}

The observation of higher levels of TPO in patients with noninfectious acute anterior uveitis raises questions relating to the cause and possible consequences of this condition.

Although TPO plays an important multifunctional regulatory role in hematopoiesis and vasculogenesis that is closely related to VEGF $^{29}$ there are many data that also relate it to inflammatory conditions. TPO is activated through the release of various proinflammatory cytokines, such as IL-1, IL-3, IL-6 and IL-11. These proinflammatory cytokines play a critical role in the triggering and development of multiple autoimmune conditions caused by dysregulation of the autoimmune response. All these cytokines interfere actively with cell immune and biochemical mediators at many levels. The regulation of this proinflammatory activity appears to be mediated by anti-inflammatory and immunosuppressive cytokines, such as IL-4, IL-10 or transforming growth factor (TGF)- $\beta .{ }^{30}$ There are several reports of a significant increase in the expression of the TPO gene under inflammatory conditions, which suggests that it acts as an acute-phase protein. ${ }^{31}$ It is also established that the synthesis of TPO in the liver can be induced by IL-6, while IL-6 stimulates thrombopoiesis through the action of TPO, and that the reactive thrombocytosis associated with some inflammatory conditions is mediated by IL- 6 through the action of TPO. ${ }^{32-34}$ A significant correlation between IL- 6 and TPO is evident in the fact that the administration of IL-6 in patients with cancer produces an increase in TPO serum levels. ${ }^{35}$

Table I TPO levels in the serum and aqueous humor of uveitis patients and the control group measured by enzyme-linked immunosorbent assay, presented along with the age and sex of subjects

\begin{tabular}{|c|c|c|c|c|c|c|c|c|}
\hline \multirow[t]{2}{*}{ Subject } & \multicolumn{4}{|c|}{ Uveitis group } & \multicolumn{4}{|c|}{ Control group } \\
\hline & $\begin{array}{l}\text { Age } \\
\text { (years) }\end{array}$ & Sex & $\begin{array}{l}\text { Aqueous humor } \\
\text { level of TPO (pg/mL) }\end{array}$ & $\begin{array}{l}\text { Serum level of } \\
\text { TPO }(\mathrm{pg} / \mathrm{mL})\end{array}$ & $\begin{array}{l}\text { Age } \\
\text { (years) }\end{array}$ & Sex & $\begin{array}{l}\text { Aqueous humor } \\
\text { level of TPO (pg/mL) }\end{array}$ & $\begin{array}{l}\text { Serum level of } \\
\text { TPO (pg/mL) }\end{array}$ \\
\hline I & 59 & $M$ & 49.2 & 35.6 & 50 & $\mathrm{~F}$ & 50.8 & 45.2 \\
\hline 2 & 53 & $\mathrm{~F}$ & 44.5 & 28.2 & 48 & $M$ & 51.2 & 43.4 \\
\hline 3 & 55 & $\mathrm{~F}$ & 32.5 & 21.1 & 52 & $M$ & 25.4 & 23.9 \\
\hline 4 & 40 & M & 47.8 & 31.2 & 46 & $\mathrm{~F}$ & 33.7 & 30.5 \\
\hline 5 & 70 & $M$ & 40.0 & 26.5 & 50 & $M$ & 50.9 & 50.7 \\
\hline 6 & 47 & $M$ & 86.3 & 61.2 & 52 & $M$ & 35.0 & 32.0 \\
\hline 7 & 45 & $\mathrm{~F}$ & 38.6 & 23.1 & 69 & $M$ & 39.5 & 40.1 \\
\hline 8 & 58 & $M$ & 65.2 & 37.6 & 75 & $\mathrm{~F}$ & 23.2 & 22.2 \\
\hline 9 & 79 & $M$ & 71.4 & 54.6 & 77 & $M$ & 30.8 & 29.3 \\
\hline 10 & 49 & $\mathrm{~F}$ & 77.1 & 33.5 & 55 & $\mathrm{~F}$ & 24.0 & 23.9 \\
\hline II & 68 & $M$ & 46.1 & 32.6 & 44 & $M$ & 27.8 & 28.4 \\
\hline 12 & 47 & $\mathrm{~F}$ & 47.5 & 26.6 & 55 & $\mathrm{~F}$ & 14.8 & 15.3 \\
\hline 13 & 38 & $M$ & 43.0 & 23.2 & 71 & $\mathrm{~F}$ & 39.0 & 41.0 \\
\hline 14 & 43 & $\mathrm{~F}$ & 69.7 & 51.4 & 64 & $M$ & 39.2 & 42.3 \\
\hline 15 & 35 & $M$ & 41.7 & 25.3 & 70 & $M$ & 34.1 & 29.2 \\
\hline 16 & 40 & $\mathrm{~F}$ & 70.9 & 54.7 & 70 & $M$ & 29.6 & 28.6 \\
\hline
\end{tabular}

Abbreviations: TPO, thrombopoietin; M, male; F, female. 


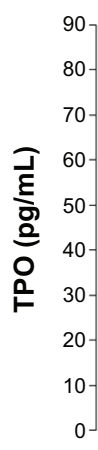

Figure I Thrombopoietin (TPO) levels in the aqueous humors of 16 patients with uveitis and 16 controls.

Notes: The horizontal lines represent the mean concentration for each group. TPO levels in the two groups were statistically significantly different (Mann-Whitney $U$-test, $P=0.0008$ ), with the concentration of TPO proving to be significantly higher among patients with uveitis than among controls.

Positive correlations have been found between TPO and C-reactive protein (CRP), but do not appear to affect platelet count. TPO acts as an acute-phase protein, and appears to be closely related to the action of IL- 6 in inflammatory conditions. ${ }^{36,37}$

In some inflammatory diseases, such as SchönleinHenoch disease, an increase in TPO has also been described along with IL-6, which is thought to be an acute-phase reactant; in fact, a secondary increase in the production of TPO has been reported in this condition. ${ }^{38}$ TPO increases related to IL- 6 have also been reported in the coronary disease inflammatory condition. ${ }^{39}$

The regulatory function of TPO has also been described in the differentiation of mast cells and its increase in patients with allergic asthma, which points to its involvement in immunoallergic conditions. ${ }^{21,22,40,41}$ The importance of platelets as major agents in the defense against infection and the induction of tissue inflammation and repair has been confirmed. ${ }^{42}$ Increases of IL- 6 and TPO in the plasma of patients with inflammatory bowel disease and in sufferers of rheumatoid arthritis have also been documented. ${ }^{42,43}$

This body of evidence suggests that the increase of TPO - characteristic of uveitis, is associated with increments of other growth factors present in the aqueous humors of patients with this inflammatory condition, such as PEDF and VEGF. ${ }^{6-9}$

Compared to the control group, TPO levels in the aqueous humor in patients with noninfectious acute anterior uveitis were significantly higher, but there was no difference detected between plasma levels of TPO in patients vs controls.

We cannot directly determine the source of TPO in aqueous humors, but we think it is possible that its increase is not a result of the rupture of the blood-aqueous barrier, but rather derived from an increase in local production. It would be important to know whether this may be related to the pathophysiology of the disease, either as a cause or consequence, since many studies have shown that TPO expression increases during many inflammatory processes. Further studies are required to consider this possibility.

On the other hand, we should also contemplate the consequences that this increase in TPO may cause in the outcome of uveitis. Several studies in experimental models of autoimmune anterior uveitis have suggested that apoptosis plays a significant role in the resolution of uveitis, since apoptosis followed by phagocytosis is critical in the reduction of cell infiltration and subsequent resolution of the condition. ${ }^{44-49}$

In addition, other studies have related an increase in TPO to the inflammatory changes occurring in some central nervous system (CNS) infections, suggesting a proapoptotic activity and a different regulation of production in the CNS to that in the liver, where it mostly occurs. ${ }^{50,51}$

One possible clinical application of this increase in TPO is its use in the modulation or resolution of uveitis. Indeed, unlike other growth factors, it is already commercially available. $^{52}$

The statistically significant increase $(P>0.001)$ of the cell growth factor TPO in the aqueous humors of patients with noninfectious acute anterior uveitis indicates an involvement of this factor in this ocular inflammatory condition, perhaps as a mechanism of the repair process and linked to apoptosis. Any further knowledge of this and other cell growth factors is likely to lead to a better understanding of the pathophysiology of uveitis and other inflammatory conditions of the eye, and will no doubt be of great help in designing new therapeutic approaches involving new molecules, such as Romiplostim or Eltrombopag, which mimic the effect of TPO. ${ }^{53,54}$

In conclusion, the enhanced levels of TPO in the aqueous humor of patients with uveitis observed in this study lead us to support a cytoprotective role of this factor in inflammatory repair processes and the recovery of tissue homeostasis.

\section{Disclosure}

The authors have no conflicts of interest in this work.

\section{References}

1. Reeves SW, Sloan FA, Lee PP, Jaffe GJ. Uveitis in the elderly; epidemiological data from the National Long-term care Survey Medicare cohort. Ophthalmology. 2006;113:307-321.

2. Read S, Mauze S, Asseman C. CD38+CD45RB (low) CD4+ T cells: a population of T cells with immune regulatory activities in vitro. Eur J Ophthalmol. 1998;28:3435-3437.

3. Dick AD. Immune mechanism of uveitis: insights into disease and pathogenesis and treatment. Int Ophthalmol Clin. 2000;40:1-18. 
4. Curnow SJ, Falciani F, Durrani OM, et al. Multiplex bead immunoassay analysis of aqueous humor reveals distinct cytokine profiles in uveitis. Invest Ophthalmol Vis Sci. 2005;46:4251-4259.

5. Simon D, Denniston AK, Tomlins PJ, et al. Soluble gp130, an antagonist of IL-6 transsignaling, is elevated in uveitis aqueous humor. Invest Ophthalmol Vis Sci. 2008;49:3988-3991.

6. Curnow SJ, Murray PI. Inflammatory mediators of uveitis: cytokines and chemokines. Curr Opin Ophthalmol. 2006;17(6):532-537.

7. Yoshida Y, Yamagishi S, Matsui T, et al. Positive correlation of pigment epithelium derived factor and total antioxidant capacity in aqueous humor of patients with uveitis and proliferative diabetic retinopathy. Br J Ophthalmol. 2007;91:1133-1134.

8. Yoshida Y, Yamagishi S, Matsui T, et al. Increased levels of pigment epithelium derived factor in aqueous humor of patients with uveítis Br J Ophthalmol. 2007;91:149-150.

9. Fine HF, Baffi J, Reed GF, Csaky KG, Nussenblatt RB. Aqueous humor and plasma vascular endothelial growth factor in uveitis-associated cystoids macular edema. Am J Ophthalmol. 2001;132:794-796.

10. Paroli MP, Teodori C, D’Alessandro M, Mariani P, Iannucci G, Paroli M. Increased vascular endothelial growth factor levels in aqueous humor and serum of patients with quiescent uveitis. Eur J Ophthalmol. 2007; 17:938-942.

11. Arai K, Lee F, Miyajima S, Miyatake N. Cytokines; Coordinators of immune and inflammatory responses. Ann Rev Biochem. 1990;59: 783-836.

12. Yanai R, Yamada N. Mitogenic and antiapoptotic effects of various growth factors on human corneal fibroblasts. Invest Ophthalmol Vis Sci. 2002;43:2122-2126.

13. Roberts AB. The ever-increasing complexity of TGF- $\beta$ signaling. Cytokine Growth Factor Rev. 2002;13:3-5.

14. Kuhl PR, Griffith-Cima G. Tethered epidermal growth factor as a paradigm for growth factor-induced stimulation from the solid phase. Nat Med. 1996;2:1022-1027.

15. Dinbergs ID, Brown L. Cellular response to transforming growth factor 1 and basic fibroblast growth depends on release kinetics and extracellular matrix interactions. J Biol Chem. 1996;271:29822-29829.

16. Nathan C, Sporn M. Cytokines in context. J Cell Biol. 1991;113: 981-986.

17. Maldonado B, Furcht LT. Epidermal growth factor stimulates integrinmediated cell migration of cultured human corneal epithelial cells on fibronectin and arginine-glycine-aspartic acid peptide. Invest Ophthalmol Vis Sci. 1995;36:2120-2126.

18. Imanishi J, Kamiyama K. Growth factors: importance in wound healing and maintenance of transparency of the cornea. Prog Retin Eye Res 2000;19:113-129.

19. Willm J, Akkerman N. Thrombopoietin and platelet function. Semin Thromb Hemost. 2006;32:295-304.

20. Begley CG, Basser RL. Biologic and structural differences of thrombopoietin growth factors. Semin Hematol. 2000;37:19-27.

21. Kuter DJ, Begley CG. Recombinant human thrombopoietin basic biology and evaluation of clinical studies. Blood. 2002;100:3547-3569.

22. Kaushansky K. Thrombopoietin and the hematopoietic stem cell. Ann NY Acad Sci. 2005;1044:139-141.

23. Kemona-Chetnik I, Bodzenta-Lukaszyk A, Butkiewicz A, DymnickaPiekarska V, Kemona H. Thrombocytopoiesis in allergic asthma. Pol Arch Med. 2007;117:9-13.

24. Heits F, Stahl M, Ludwig D, Stange EF, Jelkmann W. Elevated serum thrombopoietin and intreleukin-6 concentrations in thrombocytosis associated with inflammatory bowel disease. J Interferon Cytokine Res. 1999;19:757-760.

25. Burmester H, Wolber EM, Freitag P, Fandrey J, Jelkmann W. Thrombopoietin production in wild-type and interleukin- 6 knockout mice with acute inflammation. J Interferon Cytokine Res. 2005;25:407-413.

26. Bloch-Michel E, Nussenblatt RB. International uveitis study group recommendations for the evaluations of intraocular inflammatory disease. Am J Ophthalmol. 1987;103:234-235.
27. Jabs DA, Nussenblatt JT. The standardization of uveitis nomenclature (SUN) Working group. Standardization of uveitis nomenclature for reporting clinical data. Results of the first international workshop. Am J Ophthalmol. 2005;140:509-516.

28. Cheung CMG, Durrani OM, Murray PI. The safety of anterior chamber paracentesis in patients with uveitis. Br J Ophthalmology. 2004; 88:582-583.

29. Eguchi M, Masuda H, Kwon S, et al. Lesion-targeted thrombopoietin potentiates vasculogenesis by enhacing motility and enlivenment of transplanted endothelial progenitor cells via activation of Akt/ mTOR/p70s6kinase signaling pathway. J Mol Cell Cardiol. 2008;45: 661-669.

30. Kim EY, Moudgil KD. Regulation of autoimmune inflammation by pro-inflammatory cytokines. Immunol Lett. 2008;120:1-5.

31. Cerutti A, Custodi P, Duranti M, Noris P, Balduini CL. Thrombopoietin levels in patients with primary and reactive thrombocytosis. $\mathrm{Br}$ J Haematol. 1997;99:281-284.

32. Burmester H, Wolber EM, Freitag $\mathrm{P}$, et al. Thrombopoietin production in wild-type and interleukin-6 knockout mice with acute inflammation. J Interferon Cytokine Res. 2005;25:407-413.

33. Kaser A, Brandacher G, Steurer W, et al. Interleukin-6 stimulates thrombopoiesis through thrombopoietin: role in inflammatory thrombocytosis. Blood. 2001;98:2720-2725.

34. Ceresa IF, Noris P, Ambaglio C, et al. Thrombopoietin is not uniquely responsible of thrombocytosis in inflammatory disorders. Platelets. 2007; 18:579-582.

35. Hollen CW, Henthorn J, Koziol JA, et al. Elevated serum interleukin-6 levels in patients with reactive thrombocytosis. $\mathrm{Br} J$ Haematol. 1991;79:286-290.

36. Cerutti A, Custodi P, Duranti M, Cazzola M, Balduini CL. Circulating thrombopoietin in reactive conditions behaves like an acute phase reactant. Clin Lab Haematol. 1999;21:271-275.

37. Ishiguro A, Suzuki Y, Mito M, et al. Elevation of serum thrombopoietin precedes thrombocytosis in acute infections. Br J Haematol. 2002; 116:612-618.

38. Lin CY, Yang YH, Lee CC, Huang CL, Wang LC, Chiang BL. Thrombopoietin interleukin-6 levels in Henoch-Schönlein purpura. J Microbiol Immunol Infect. 2006;39:476-482.

39. Cotton JM, Hong Y, Hawe E, et al. Rise of circulating thrombopoietin following cardiothoracic surgery is potentiated in patients with coronary atherosclerosis: correlation with a preceding increase in levels of interleukin-6. Thromb Haemost. 2003;89:538-543.

40. Wolber EM, Fandrey J, Frackowski V, Jelkmann W. Hepatic thrombopoietin mRNA is increased in acute inflammation. Thromb Haemost. 2001;86:1421-1424.

41. Migliaccio AR. Role of thrombopoietin in mast cell differentiation. Ann NY Acad Sci. 2007;27:152-174.

42. Klinger MH, Jeikmann W. Role of blood platelets in infection and inflammation. J Interferon Cytokine Res. 2007;22:913-922.

43. Heits F, Stahl M, Ludwig D, Stange EF, Jelkmann W. Elevated serum thrombopoietin and intreleukin-6 concentrations in thrombocytosis associated with inflammatory bowel disease. J Interferon Cytokine Res. 1999; 19:757-760.

44. Yu HG, Chung H, Lee WJ. Apoptosis of CD4 ${ }^{+} \mathrm{T}$ cells occurs in experimental autoimmune anterior uveitis (EAAU). Clin Exp Immunol. 1999; 118:357-363.

45. Yang P, Herzberg NH, Zhou H, Broersma L, de Smet M, Kijlstra A. Apoptosis of infiltrating cells in experimental autoimmune uveoretinitis. Chin Med J. (Engl) 2000;113:643-646.

46. Poulaki V, Mitsiades N, Mastorakos G, Caspi RR, Chrousos GP, Bouzas E. Fas/Fas ligand-associated apoptosis in experimental autoimmune uveoretinitis in rodents: role of proinflammatory corticotropinreleasing hormone. Exp Eye Res. 2001;72:623-629.

47. Smith JR, Hart PH, Standfield SD, Coster DJ, Wing SJ, Williams KA Apoptosis is a prominent feature of acute anterior uveitis in the Fischer 344 rat. Br J Ophthalmol. 2000;84:205-211. 
48. Li Q, Sun B, Matteson DM, O’Brien TP, Chan CC. Cytokines and apoptotic molecules in experimental melanin-protein induced uveitis (EMIU) and experimental autoimmune uveoretinitis (EAU). Autoimmunity. 1999;30:171-182.

49. Jha P, Matta B, Lyzogubov L, Tytarenko R, Bora PS, Bora NS. Crucial role of apoptosis in the resolution of experimental autoimmune anterior uveitis. Invest Ophthalmol Vis Sci. 2007;48:5091-5100.

50. Reinhol A, Zhang J, Gessner R, Felderhoff-Mueser U, Obladen M, Dame C. High thrombopoietin concentration in the cerebrospinal fluid of neonate with sepsis and intraventricular hemorrhage may contribute to brain damage. J Interferon Cytokine Res. 2007;27:137-145.
51. Ertenli I, Kiraz S, Oztúrk MA, Haznedaroglu I, Celik I, Calgüneri M. Pathologic thrombopoiesis of rheumatoid arthritis. Rheumatol Int. 2003; 23:49-50.

52. Stasi R, Evangelista ML, Amadori S. Novel thrombopoietic agents: a review of their use in idiopathic thrombocytopenic purpura. Drugs. 2008;68:901-912.

53. Haznedaroglu IC, Goker H, Turgut M, Buyukasik Y, Benekli M. Thrombopoietin as a drug: biological expectations, clinical realities, and future directions. Clin Appl Thrombosis/Hemostasis. 2002;8:193-212.

54. Wadhwa M, Thorpe R. Haematopoietic growth factors and their therapeutic use. Thromb Haemost. 2008;99:863-873.
Clinical Ophthalmology

\section{Publish your work in this journal}

Clinical Ophthalmology is an international, peer-reviewed journal covering all subspecialties within ophthalmology. Key topics include: Optometry; Visual science; Pharmacology and drug therapy in eye diseases; Basic Sciences; Primary and Secondary eye care; Patient Safety and Quality of Care Improvements. This journal is indexed on

\section{Dovepress}

PubMed Central and CAS, and is the official journal of The Society of Clinical Ophthalmology (SCO). The manuscript management system is completely online and includes a very quick and fair peer-review system, which is all easy to use. Visit http://www.dovepress.com/ testimonials.php to read real quotes from published authors. 